\title{
Human Resource Strategy Evaluation And Performance in Higher Education: An Empirical Study on Selected Universities in Kenyan
}

\author{
Isaac. M. Ole Sopia' \\ Simon K. Kipchumba \\ Ronald K. Chepkilot ${ }^{3}$ \\ Department of Business Administration, Kabarak University, Kenya ${ }^{1 \times 3}$ \\ Department of Business Administration, Egerton University, Kenya ${ }^{2}$
}

\begin{abstract}
The research aimed to examine the relationship between human resource strategy evaluation and the performance of human resources in universities in Kenya. A sample survey cross-sectional design was employed where the target population was the registrars from the administration department that has oversight over the human resources. The data was then processed using the SPSS version 25 and analysed with descriptive and inferential statistics. Frequency distributions indicated high utilisation of the principles of business strategy evaluation in human resources. The correlation between the Human resource Strategy Evaluation and performance was positive and significant, and regression analysis confirmed the predictive power of human resource strategy on performance. The study concluded a positive and significant relationship between the utilisation of human resource strategy evaluation and the performance of human resources in universities in Kenya.

Keywords: Human Resource Strategy Evaluation; Performance; Higher Education, Kenya
\end{abstract}

*Corresponding author: Isaac. M. Ole Sopia; Email: masibayi@kabarak.ac.ke DOI: https://doi.org/10.37227/JIBM-2021-05-832

\section{Introduction}

The notion that human resources are the most significant asset in organisations (Bhusan \& Sar, 2020; Shrouf et al., 2020; Chakraborty \& Biswas, 2019) is uncontested. This owes to 'the totality of knowledge, skills, attitudes, personality traits, talents, relationships, networks' that are person-based (Simonis, 2021) and pervade systems. This argument is in line with the resource-based view (RBV) of the firm that privileges internal resources and capabilities in the competitiveness of entities (Barney, Corte, Sciarelli, \& Arikan, 2012). The reasoning is even more pertinent for universities as labour-intensive institutions (Jyot \& Mohsin, 2020). In contention, though, are the approaches to harnessing slack in these resources.

Important as people are, they have to get organised. Human resource strategy is one such organising paradigm and is presently the choicest. Strategic human Resource Management contains strategy (Sepahvand \& Khodashahri, 2021), which is a 'central philosophy of the way that people in the organization are managed and the translation of this 
into personnel policies and practices' (Torrington \& Hall, 2008). Thus, in theory, it is distinguishable from personnel and human resource management. The strategy seeks to influence people through policies and practices; people then impact organisational purpose (Colbert, 2017). Since people design and execute organisational activities, human resource strategy has implications for the overall performance, however winding the path is. Notably, human resource has co-evolved with strategic management from the beginning in the early 1980s (Lengnick-Hall, Lengnick-Hall, Andrade, \& Drake, 2009).

Universities in Kenya have been intense in strategic planning over the past two decades in response to contextual shifts. According to Kafel and Ziebicki (2021), the advent

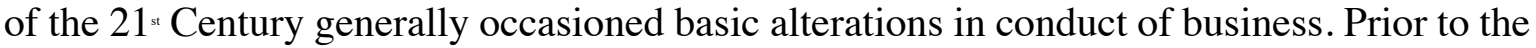
year 2002, the institutions were tightly state-regulated. Indeed, the country itself was, to a certain extent, insulated from some external pressures. As the country became more open, when challenges facing universities mounted, with regulatory and budgetary pressures being the most pronounced. The number of institutions also increased, suggesting increased competition and even hyper-competition, predisposing administrators to embrace marketlike approaches, among them strategy. Strategic planning process was put on the front burner. Kiprop, Bomett, and Michael (2015) reported the decree of the Ministry of Education for institutions to embrace strategic planning. Most institutions embraced the five-year planning cycle, and most are in their fourth cycle of the process.

Criticisms on strategic planning revolved around failed implementation. Strategic Management focused on implementation to address this aspect. Implementation depends on people-based action, reinforcing people-based initiatives. Thus, human resource strategy is an entity's general plan for organising its human side to align it with its business activities (Van Vulpen, 2020). Wright (2008) considered human resource strategy a system of human resource practices about a certain job or collection of jobs that aims at the best worker performance possible to meet goals, and depends on 'what people feel, have, and then do'. This is analogous to a product strategy. According to the Republic of Kenya (2017), human resource strategy is a plan of action designed to develop the skills, attitudes, and behavior among staff to help organisations meet their goal; principles for managing the workforce through human resource policies and practices are at the heart of human resource strategy. Suffice to say, the human resource strategy sets the direction for all the key areas of human resource classified under the acquisition, maintenance, and separation with people (Mezentsevaet al., 2018).

Human resource strategy is a functional level strategy (Wright, 2019); however it is restricted in scope (Urmila, n.d.). Yet human resource is not confined to the human resource unit; the function covers the entire organisation as it services other subsystems. The strategy transcends the traditional disciplines in the acquisition of, maintenance of, and separation with, organisational members to cover culture and organisation (Thomas, 1996) as well as issues outside the organisation such as corporate social responsibility (CSR) and diversity considering the incidence of human resource societal objectives (Aswathappa, 2008). It is necessary to consider the performance of the human resource function in a broader view. Together with other functional strategies in operations, marketing, finance, research and development among others, human resource strategy enables competitive strategy, which in turn enables corporate strategy, where the two are distinct.

The overriding benefit of human resource strategy is its impact on the workforce that then affects organisational performance (Colbert, 2017). The nexus, however, between human resource and organisational objectives and performance gets somewhat convoluted. Taking the rationalistic approach to the strategy process (Serforntein, 2016), human resource 
cascades from corporate strategy through the business strategy. Put differently, human resource aligns upwards with corporate level strategy through business level strategy (Wright, 2019), in the case where the top two strategies are distinct. Although the direct impact of human resource is moot, intuitively it exists. Looking at the vital role of human resource in strategy implementation, a shift is taking place from mere alignment to strategy integration (Boon, Eckardt, Lepak \& Boselie, 2017; Urmila, n.d.) and probably to leadership of strategy. To support corporate and business strategies, human resource addresses the four human resource management objectives: personal; functional; organisational; and societal (Aswathappa, 2008). Evidently, the performance of the human resource has implications for the sustainable performance of entities. But the question is how to establish that human resource is performant, which throws evaluation into the fray.

The purpose of strategy evaluation is to show that strategy does contribute to overall performance via efficiency, effectiveness, and impact (Torrington, 2008). Since human resource cascades from business strategy, this paper postulates that the evaluation of human resource ought to follow the same principles scholars use to evaluate BS. But literature in support of this postulation is scarce. According to Rumelt (1979) as cited by Forsell (2012), to evaluate business strategy takes cognizance of the four principles: Consistency; Consonance; Feasibility; and Advantage. This study sought to examine the extent to which these dimensions can be utilised in the assessment of the human resource strategy, and in particular, its relationship to the performance of that strategy.

Human strategy evaluation should reinforce claims of the strategic role of the human resource management function. Yet strategy evaluation is generally under-researched (Hieu \& Nwachukwu, 2019; Forsell, 2012). Actually, human strategy evaluation as a concept is rare in strategic human resource management discourse. Common relevant concepts include performance appraisal and human resource audits. Literature on strategic human resource management practices (Ayanda \& Sani, 2011; Fan \&Wang, 2015; Eneh \& Awara, 2016) has not indicated any attempts to examine the nature of human strategy evaluation or to domesticate the dimensions of business strategy evaluation above to the human resource strategy evaluation generally, and specifically in the context of higher education in Kenya, and their relationship to the performance of the human resource strategy in question. Therefore, this study has been conducted to fill this significant gap in the current literature.

\section{Human resource Strategy Evaluation}

\section{Literature Review}

From Latin 'Valupure' (Priyan \& Oinam, 2015), evaluation denotes assessment of the worth or value. The Canadian Evaluation Society (CES, n.d.) considers evaluation in three aspects: design; implementation; or results. Evaluation entails taking measurement in some way or other, and making judgement about results of that measurement. Data, therefore, is at the heart of this process. 'Without data,' Edward Deming is famously quoted, 'you're just another person with an opinion' (Van Vulpen, 2020).

In strategy, evaluation entails questioning the strategy (Wright, 2019; Hieu \& Nwachukwu, 2019) lest, in particular, it leads to more serious problems than currently exist. Evaluation, ideally, occurs at three levels: choice; implementation; and results. Digman (2003) identifies two types of evaluation: assessment of alternatives for strategic choice; and establishing suitability of an existing strategy, thereby throwing light on the efficiency and effectiveness of the strategic plans. In addition, Yadav (2011) also views two roles of evaluation at two levels: the strategic level that questions consistency; and the operational level that tracks implementability. This second role, though, is to monitor or control. This 
study assumed an existing human resource strategy, the evaluand, presumably embedded in the existing strategic plans at universities. That evaluation is essentially the measurement underscores the need for effective indicators. A challenge for human resource has been the shortage of effective quantitative indicators (Coron, 2021 citing Lismontet al., 2017)

Maunder et al. (2014) have listed the objectives of evaluation as: to confirm that strategy will work as envisaged; to establish the strategy to meet pre-determined targets; to establish a cost-benefit analysis; and to monitor progress at the strategy execution and take corrective measures or institute improvements as necessary.

Human resource strategy evaluation has basis in strategic management theory. Attempts At conceptualisation of strategic management always run into difficulty; and definitions are always mouthful. But all definitions are similar in that strategic management is about an entity's objectives and the means to attain them (Omalaja \& Eruola, 2011; Pearce \& Robinson, 1991 as cited by Palladan, \& Adamu, 2018). The definition of Dess et al. (2007) captured by Athapaththu (2016) is instructive is germane: it is a process and a path guiding action all over the organisation. 'All over the organisation' implies that human resource activities are part of the strategy and 'action' implies task execution. Essentially, strategic management is the deployment of a plan in pursuit of business objectives. Strategy, from Greek Stratego, has roots in military thought and refers to military leadership (Palladan \& Adamu, 2018). It was embraced by management after World War II in response to a changing environment (Athapaththu, 2016). The process has put leverage on strategy implementation (Wright, 2019) and the vital role of human resource, for people are indispensable in the multi-phased the process.

Strategy bears a number of distinct characteristics. For this reason, scrupulous attention to the process is imperative. Strategy is concerned with large issues, is multibusiness and cross-functional in nature, thus affecting entire entities and are, therefore, consequential, focuses on environmental questions, particularly external ones, is futuristic in orientation, takes an uncertain long term, and call for stretch of resources (Wheelen \& Hunger, 20011; Johnson \& Scholes, 2008). Strategy costliness implicates the sustainability of entities. Its contribution to performance is, therefore, of major interest to scholars and practitioners. The performance of strategy depends on two conditions: whether the choice of the strategy was sound; and how successfully the strategy was executed. Strategy evaluation assesses both the validity of the strategic choice process as well as the measurement and examination of the performance of the strategy chosen for its contribution to the overall success of the strategising entity. Thus, strategy evaluation is a vital step in the strategy process.

Cascading human resource strategy from corporate and business strategies rests on the notion of strategy structure or strategy hierarchy, which entails corporate, business, and functional strategies. Strategy process, on the other hand, is management that is strategic. The former is a pyramidal arrangement of strategy from the highest to the lowest levels. Strategic management is processual, presented in phases. For some authors such as Wheelen and Hunger (2011), it is four-phased: environmental analysis; strategy formulation; strategy Implementation; and Strategy evaluation and control. Others (Bratton \& Gold, 2017; Certo \& Peter, 1993) adopt a five-step approach: analysis; setting organisational direction; strategy formulation; strategy implementation; and strategy evaluation and control. According to the rationalistic approach (Calabretta, Gemser \& Wijnberg, 2017), strategy evaluation and control is the final phase of the strategy process. Contrary to Wright (2019), evaluation begins at the start of the strategy process. 


\section{Human Resource Strategy Evaluation Framework}

According to Rumelt (1993) as cited by Ghosh (2010) and (David 2013), business strategy evaluation is based on four principles of Consistency, Consonance, Advantage, and Feasibility. Consistency looks out for agreement among goals and policies (emphasizing goal congruence); it refers to the fit between the strategy formulated and the entity's key internal elements notably mission, values, and long-term objectives. Consonance refers to the alignment of the entity with its external environment, focussing on sets of trends or individual trends in the political, economic, social, and technological milieu. Consonance staves of strategic drift, fostering organisational legitimacy. Advantage questions the capacity of strategy to cause and/or sustain competitive advantage via resources, skill, and position. Feasibility concerns with the appropriateness of strategy vis-à-vis available resources and assurance that strategy will not cause more unsolvable problems (ibid.). David (2013) noted consonance and advantage are based on external circumstances: consistency and feasibility on internal dynamics.

Configuration stresses on internal fit (Oxford Reference, 2020), the development of coherent bundles of human resource practices that reinforce one another, and revolving around human resource key activities of acquisition, maintenance, and separation. An appropriate configuration of human resource is also suggested that involves fit with the business strategy in an human resource operationally reactive, human resource operationally proactive, human resource strategically reactive, human resource strategically proactive manner (Ali, Ahmad, \&d Iqbal, 2012). Only strategically proactive human resource establishes internal and external fit, thereby creating viable strategic substitutes.

For Tilles (1963) in Ghosh (2010), there are six evaluation indicators as follows: internal consistency; external consistency; resource considerations; level of risk strategists will tolerate; soundness of the time horizon; and the workability of strategy. While Rumelt (1993, in David 2013) focuses on internal consistency and assigns the external dimension to consonance, Tilles (1963 in Ghosh, 2010) splits consistency into internal and external, giving it more clarity. For Digman (2003), objective strategy evaluation criteria cover three items: good consistency; strategy content; and implementation. But Digman (2003)'s use of the term objective is confusing since these criteria involve qualitative statements rather than the traditional objective measures that are quantitative in nature.

Good consistency requires strategy alignment with mission, goals and objectives. Digman (2003) recommends six qualitative statements for strategy content and seven for implementation in questioning the strategy. The present study seeks to link these criteria to the human resource strategy. To operationalise evaluation, Certo and Peter (1993) recommended that strategists ask critical questions around the qualitative evaluation indicators. But quantitative indicators of performance among them returns on investment, return on equity, earnings per share, liquidity measures (ibid.) are also considered. These are, however, focused on short, annual target (David, 2013). The challenge of the human resource function has been to establish quantitative measures of not only the human assets (Mello, 2011) but the following high impact initiatives: recruitment; selection, and orientation; career development and training; compensation; evaluation, discipline, and control; and labour relations and equal opportunity requirements (Pearce \& Robinson, 2011; Ghosh 2010). Assessment at higher education institutions is more inclined to be qualitative than quantitative. Apart from the qualitative and quantitative indicators, there are other considerations of strategy evaluation: frequency of the exercise; methods to be deployed; expertise of evaluators; and ownership and uptake of evaluation results. 
Despite the obvious benefits, there is little evidence that scholarly attention is paid to this phase of strategising (Hieu \& Nwachukwu, 2019). If Strategy evaluation is less researched (Forsell, 2012), then the situation is direr for human resource strategy evaluation. The human resource strategy of the Ministry of Health has a seemingly rigorous 'monitoring and evaluation' regime. But the dimensions of business strategy are not employed. Literature suggests that a strategy that meets these criteria will enhance the competitiveness.

\section{Performance}

Organisations and their subsystems exist to accomplish something; that is to perform (Orajaka (2021), the production of a valued result. Performance is the centrepiece of all management effort; arriving, though, at a universal conceptualisation of the construct presents difficulties (Sharma \& Al Sinaw, 2021; Tahir, 2020), chiefly for its polysemantic nature (Elena-Iuliana \& Maria, 2016). It is an even more uphill task for service-based entities, among them universities. Performance reflects the functioning of 'economic entities' (Pintea \& Achim, 2013) and thereby confers legitimacy upon them. Performance is that which contributes to improved cost-value (Elena-Iuliana \& Maria, 2016, citing Philippe Lorrino, 1997). According to Matei (2006) as cited by Elena-Iuliana and Maria (2016), performance is at the confluence of mission, resources, and service quality results. Yet performance is not a fixed point but a journey; hence the notion of level of performance (Egler, n.d.). In human resource management, the challenge is more intractable due to less rigorous performance indices. Still performance is very much a human resource issue and at its heart are behaviours of individual employees (Mello, 2011; Khan, Taher, and Islam, 2021).

Concern with performance in the world today is for proof that entities create value to the satisfaction of myriad stakeholders. This brings to the fore concern for data-yielding key performance indicators. Validation of performance is in its measurement and indicators serve as proxy. According to Loukkola, Peterbauer, and May (2020), the validity of demand in higher education institutions and their stakeholders 'for an evidence-based, data-driven analysis of higher education and its performance' is undisputed. Among measures of performance in universities include university rankings (Vidal \& Ferreira, 2020), academic service quality (Sharma \& Al Sinaw, 2021), student outcomes (Gonzalez, de la Rubia, Hincz, Comas-Lopez, Subirats, Fort, 2020), financial issues (Montanaro, 2013), and the role of individual human resource disciplines and employee performance. Rarely has the performance of the human resource management strategy been inquired into. The investigation reported herein sought to inquire into the efficiency, effectiveness, and impact as indicators of the human resource strategy performance in universities in Kenya.

The organisational effectiveness model anchors the performance construct in most discussions. They include the goal approach, the systems resource approach, the process approach, and the strategic constituency approach (Ashraf \& Kadir, 2012). Most key performance indicators in higher education are goal-based since most activities revolve around the goals on teaching, research, and service. Accordingly, key performance indicators are derivatives of the goals and objectives of universities. Similarly, as supportive functions, human resource management practices derive from missions and objectives as will relevant metrics.

\section{Conceptual Framework}

From a statistical perspective, the conceptual framework describes the relationship between the main concepts of a study (Adom, Hussein, \& Agyem (2018). It is arranged in a logical 
structure to provide a picture or visual display of how ideas in a study relate to one another (Grant \& Osanloo, 2014). This study conceptualised human resource strategy evaluation, the independent variable, in terms of consistency, consonance, feasibility, and advantage; and the performance of the human resource strategy, the dependent variable, as human resource efficiency, human resource effectiveness, and human resource impact.

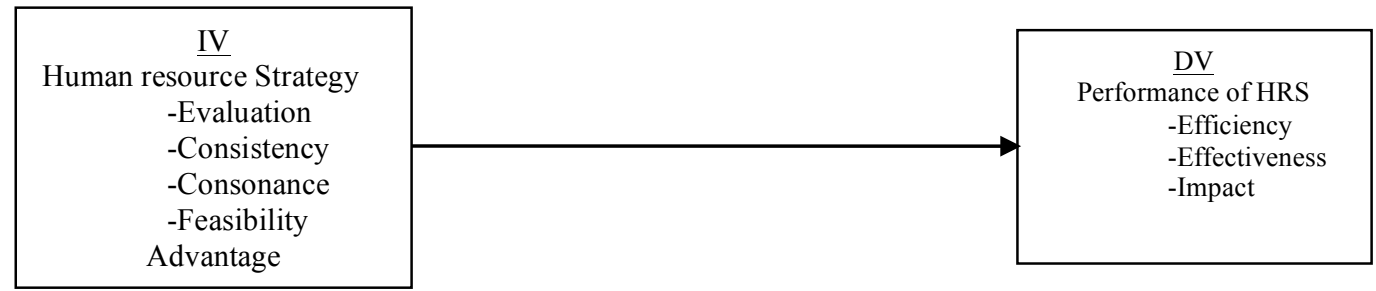

Figure 2.1: Conceptual framework of human resource strategy evaluation and performance.

\section{Research Design}

\section{Research Methodology}

Based on science, resolving research problems is systematic and organised, with key steps being logically laid down. This is the basis of the concept of research design as the blueprint for conduction of investigations. Kothari (2004) considers the research design to be the logical framework or structure that generates desired evidence in an accurate, unbiased, and economical way to minimise the incidence of invalid conclusions. It involves operations for gathering information as well as the logic behind those operations, which provides this chapter to the Research Method(ology), that is, the methods and their logic.

This study adopted the cross-Sectional sample survey, which is snapshot in nature, captures the phenomenon of interest at a point in time. According to the USCL (2016), design focuses on studying and drawing inferences from existing differences between people, subjects, or phenomenon, is amenable to use of data from a large number of subjects, and is not geographically bound. These attributes were germane to this study. Practical research work can, however, be hardly said to be mutually exclusive; within this crosssectional type, traces of exploration, description, and explanation would be found. There are drawbacks that can be pointed out of cross-sectional studies: one, similar subjects can be difficult to find. Secondly, as Bayo-Moriones and de Cerion (2002) noted, these designs do not establish causality. Thirdly, in a fluid environment such as the one attending to HEIs in Kenya, snapshot results, results that are static and time-bound, historical, or temporal, could vary with time and slowly become obsolete . Lastly, events in the real world are hardly sequential, which precludes one from building on the past. Nevertheless, cross-sectional studies continue to be the design of choice for most postgraduate programmes.

\section{Population and Sampling Technique}

A statistical population comprises the collection of all possible observations of a specified characteristic of interest (Lapin, 1990). It is from this collectivity (also referred to as universe, target population, or theoretical population) that the accessible population can be derived (Asiamah, Mensah, \& Oteng-Abayie, 2017). Population is central to a research as it bears the characteristics under investigation, hence the criticality of accessibility. There are a total of 74 universities in Kenya classified as follows: 31 chartered public universities; 18 chartered private universities; 14 universities with Letter of Interim Authority (LIA); six 
constituent colleges of public universities; and five constituent colleges of private universities (CUE, 2017). A representative sample was drawn from this population.

The unit of analysis was the university human resource unit. The respondents were the Registrar (Administration) who has the responsibility including that of the human resource function. According to Kazmi (2008), participants in strategic control include: members of the board of directors; chief executives; SBU and profit-centre heads; financial controllers, company secretaries, internal and external auditors; and middle level managers. Within the university context, the Registrar (Administration) listed as among the 'chief officers of the university' fell within this classification. Universities in Kenya are caught in the grip of change and crisis, to which their response is intensified strategic planning. As service entities, labour is the largest of their inputs, which is an onerous responsibility for their human resource units. The institutions, therefore, provide an ideal setting for investigating the workability of human resource strategy evaluation. As the research got underway, fresh demands were issued to the universities to begin to work out and submit to the authority modalities for merging.

Table 3.1: Study Population by University

\begin{tabular}{lcc}
\hline University category & Frequency & Proportion \\
\hline Chartered Public & 31 & $42 \%$ \\
Public Constituent Colleges & 06 & $08 \%$ \\
Chartered Private & 18 & $24 \%$ \\
Private Constituent Colleges & 05 & $07 \%$ \\
With Letter of Interim Authority & 14 & $19 \%$ \\
Total & $\mathbf{7 4}$ & $\mathbf{1 0 0 \%}$ \\
\hline
\end{tabular}

Source: Commission for University Education, Kenya (2017)

\section{Sample Size}

The researcher picked the study sample in such a manner as to assure representativeness and economy in the elicitation of the required data. Three key statistical considerations for sample size determination were used: level of accuracy sought; level of confidence; and estimate of the proportion of the population thought to carry or not to carry the characteristic the researcher sought to investigate (Vernoy \& Kyle, 2002; Lapin 1990; Shughnessy, Zechmeister, \& Zechmeister, 2006). Thus, the research employed Yamane's formula for sample size computation: $n_{r}=N /\left(1+N e^{2}\right)$. The population size of the universities was 74 (CUE, 2017). Substituting these quantities into the first equation gave a required sample size of 62.4472 , or approximately 62 . For finite populations, adjustment on this value was required and done using the finite population correction factor formula, $n_{a}=n_{r} /(1+$ $\left[\frac{n_{r}-1}{N}\right]$, yielding the adjusted sample size of 33.98 , rounded off to 34 . 


\section{Data Collection, Type and Source of Data}

\section{Instrumentation}

The research elicited data using self-administered questionnaires, an instrument of choice for survey research. Being self-administered, this instrument was fast, cost-effective and generated large amounts of data. The tool was in two parts: Part I comprising preliminary information; and Part II comprising five sections on human resource strategy evaluation, human resource strategy control, information characteristics, top management support, and performance.

The preliminary section consisted of open and closed-ended items. Statements on the indicators of the study variables were adequately and comprehensively grounded in the literature reviewed, for example Boudreau \& Lawler (2016), Beuren and Teixeira (2014), and Snell (1992). The items were scored on a five-point Likert-type scale. The researcher borrowed from literature the established principles of instrument construction including appropriate wording, avoidance of emotional language and prestige bias, and careful approach to sensitive information (Neuman, 2011), and researcher commitment to and promise of confidentiality (Salkind, 2000). As an experienced and well-informed member of senior management, the Registrar (Administration) was expected to have no difficulty in comprehending and responding to the statements made on the instrument.

\section{Test of Validity and Reliability}

The study tested the instrument for content validity and reliability. Validity was tested using the Lawshe's method (Lawshe, 1975, as cited by Ayre and Scally, 2013), that is CVR $=\mathrm{N}_{\text {e }}$ - (N/2)/(N/2), where CVR stands for content validity ratio, $\mathrm{N}$ is the number of panel members and $n_{c}$ is the number of panel members who consider the construct essential. Six experts reviewed the constructs, all of them found the constructs essential $\left(\mathrm{CVR}_{\text {criiual }}=1.00\right)$ From the validity formula $C V R=\left(\mathrm{N}_{\mathrm{e}}-\mathrm{N} / 2\right) /(\mathrm{N} / 2)$ as for example in Zamanzadeh et al. (2015). Reliability was determined using the Cronbach's alpha, $r=\propto=N /(N-1)\left(S^{2}-\right.$ $\left.\frac{\sum S_{i}{ }^{2}}{S^{2}}\right)$. The reliability coefficients for HSE and performance were 0.873 and 0.886 respectively, which met the threshold of acceptability (Taber, 2018).

\section{Data Collection Procedure}

As required by the regulations, the researcher, on the recommendation of the Kabarak University, sought the National Commission of Science, Technology, and Innovation (NACOSTI) authorisation to collect data. Armed with the research permit, the researcher established the initial contact with the administrations of the sampled universities to obtain telephone numbers and email addresses. Four research assistants were tasked with making prior notification by telephone.

Information security has become a global issue, which may be restrictive about releasing information to researchers. Thus, to foster co-operation, avert non-response, and thereby increase the response rate, the researcher addressed the introductory letter personally to the Vice Chancellor to request clearance for the Registrar to participate in the research. A total of 34 letters were mailed, with a cover letter enclosed. The research assistants made follow-up by telephone and, in some cases, physical appearance. 


\section{Method of Data Analysis}

Borrowing from Gupta (1969), the researcher cleaned and edited the returned instruments for completeness, consistency, accuracy, and homogeneity. This generally afforded the researcher an overview of what to expect from data (Shughnessy, Zechmeister, and Zechmeister, 2006). Items were then coded and entry made into the Statistical Package for Social Science (SPSS) Version 25. Various outputs were generated and printed from the SPSS, including descriptive, summary, and inferential statistics. As the quantitative data were generated, the researcher deployed tools for handling numerical evidence in making decisions (Lapin, 1990).

The researcher used descriptive statistics to summarise and present processed data (Franfort-Nachmias and Leon-Guerrero, 2011), presenting summarised data in tables (Lapin, 1990). This gave a general shape of the frequency distributions and thereby facilitated further analysis (Vernoy \& Kyle, 2002). Advanced techniques in correlation and regression analyses were deployed to establish the relationships among the variables at the specified statistical significance as compared with practical or scientific significance (Shughnessy, Zechmeister, \& Zechmeister, 2006). In addition, the researcher employed the Analysis of Variance (ANOVA) to countercheck model adequacy. The objective in the study involved a direct relationship between the independent and dependent variables. To determine the direct relationship, the researcher used the following regression model: $Y=\beta_{0}+\beta_{1} X+\varepsilon$, where, $\mathrm{Y}=$ the dependent variable; $X=$ independent variable, HSE, $\beta_{0}=$ constant or intercept, $\beta_{1}$, $=$ coefficient of independent of the variable; and $\varepsilon=$ error or disturbance term.

\section{Results and Discussion}

\section{Utilisation of the Human Resource Strategy}

The utilisation of the human resource strategy evaluation constituting consistency, consonance, feasibility, and advantage, was measured on a five-point Likert-type scale. The results of individual indicators were summed up into a composite score as Table 3.2 shows.

Table 3.2: Overall Levels of Utilisation of Human Resource Strategy Evaluation

\begin{tabular}{lrr}
\hline Overall Level of Utilisation & Frequency & Percentage \\
\hline Low & 0 & 0.0 \\
Moderate & 12 & 38.7 \\
High & 24 & 61.3 \\
Total & 31 & 100.0 \\
\hline
\end{tabular}

As the table above indicates, 38.7 percent (12) of the respondents rated moderate while 61.3 percent (19) of the respondents rated high the utilisation of human resource strategy evaluation at universities in Kenya. None reported low levels of utilisation of human resource strategy evaluation. This suggests that the principles of business strategy evaluation are relevant to the evaluation of the human resource strategy, a functional level strategy. This not only reinforces the cascading of the human resource strategy from the business strategy but is also attributed to the growing need for the human resource management function to assume a greater role in the strategy process and support competitiveness of organisations.

Universities are labour-intensive; it was thus, expected that people issues will take centre stage. It can also be inferred that human resource will be at the heart of strategic plans, even if it is not regarded as such. The ordinal rating scales is also consistent with other human resource performance ratings such as "acceptable," "effective" and "very effective" (Society 
of Human Resource Management, n.d.). Amaeshi (2013), however, decries too much emphasis on intermediary rather bottom-line performance indicators.

This overall finding is consistent with Allui and Sahni (2016), Muraga (2015), Bodor (2014), Ayanda and Sani (2011). Allui and Sahni (2016)'s study reported a strong level of awareness of strategic human resource management among Saudi higher education institutions. Muraga (2015) found a direct effect of strategic human resource management practices on performance of parastatals in Kenya. Bodor (2014) found the presence of modern human resource management in Hungarian universities. In Ayanda and Sani (2011)'s study, human resource management was found to be moderately integrated into the strategy and operations of HEIs in Nigeria.

\section{Performance of the Human resource Strategy}

The study sought to establish levels of performance of the human resource strategy at universities in Kenya. The overall performance measured efficiency, effectiveness, and impact. The variable was measured on a five-point Likert-type scale and individual results summed up into a composite score. Table 3.1 indicates that $58.1 \%$ of the respondents rated overall performance $3.2 \%$ low, moderate, $38.7 \%$, and high.

Table 3.1: Overall Levels of Performance of Human resource Strategy

\begin{tabular}{lrr}
\hline Overall Level of Utilisation & Frequency & Percentage \\
\hline Low & 01 & 3.2 \\
Moderate & 18 & 58.1 \\
High & 12 & 38.7 \\
Total & 31 & 100.0 \\
\hline
\end{tabular}

This suggests consciousness about the theorised human resource strategy performance indices in universities in Kenya is moderate to high, though moderate is the modal rating. Universities are labour-intensive; it is thus expected that people issues will take centre-stage. It can also be inferred that human resource strategy will be at the heart of strategic plans, even if it is not thus named. The ordinal rating scales is also consistent with other human resource performance ratings such as "acceptable," "effective" and "very effective" (SHRM, n.d). This finding is consistent with Allui and Sahni (2016), Muraga (2015), Bodor (2014), Ayanda and Sani (2011). Allui and Sahni (2016)'s study reported a strong level of awareness of SHRM among Saudi HEIs. Muraga (2015) found a direct effect of SHRM practices on performance of parastatals in Kenya. Bodor (2014) found the presence of modern human resource management (SHRM) in Hungarian universities. In Ayanda and Sani (2011)'s study, HRM was found to be moderately integrated into the strategy and operations of HEIs in Nigeria. But according to Amaeshi (2013), too much emphasis on intermediary rather bottom-line performance indicators is unsatisfactory.

\section{Test of the Hypothesis}

The study sought to test the hypothesis of non-significance on the relationship between utilisation of human resource strategy evaluation and the performance of the human resource strategy. To achieve this, the investigator summarised the findings and then performed correlation and regression analyses to establish their levels of significance. 


\section{Significance of Correlation}

Using the Pearson's Product Moment Correlation Coefficient $(r)$, the study sought to establish the association of the independent variable and dependent variable. Pearson's Product Moment Correlation Co-efficient $(r)$ is a method of statistical relationship used to measure the degree of relationship, in terms of strength and direction, between two or more variables (Gupta, 1969). The goal is to establish the extent the two variables covary and to quantify the strength of the relationship between them. For the method to be used, the two variables were quantified and measured on a continuous (ratio/interval) scale using the generated composite index scores; the utilisation of human resource strategy evaluation index score, and performance index score. Thus, the human resource strategy evaluation index score (and the indices of its dimensions) constituted the independent variable, while human resource strategy performance index score was the dependent variable.

The relationship between the calculated $p$ value and the significance value $(\alpha)$ formed the basis for rejection and non-rejection of the null hypothesis; with $p<(\alpha)$ for significance and $p>(\alpha)$ for non-significance (Schuman et al., 2018). Table 3.3 displays a summary of the correlation coefficient matrix of human resource strategy evaluation and performance of institutions.

Table 3.3: Correlation Coefficient Matrix of HSE and Performance

\begin{tabular}{llc}
\hline \multirow{2}{*}{ Overall utilisation of HSE } & $R$ & Performance index score \\
index score & Sig. (2-tailed) & $.608^{* \prime}$ \\
& $\mathrm{N}$ & .000 \\
Consistency index score & $R$ & 31 \\
& Sig. (2-tailed) & .400 \\
& $\mathrm{~N}$ & .026 \\
Consonance index score & $R$ & 31 \\
& Sig. (2-tailed) & $.471^{* \prime}$ \\
Advantage index score & $\mathrm{N}$ & .007 \\
& $R$ & 31 \\
& Sig. (2-tailed) & $.530^{*}$ \\
Feasibility index score & $\mathrm{N}$ & .002 \\
& $R$ & 31 \\
& Sig. (2-tailed) & .539 \\
& $\mathrm{~N}$ & .002 \\
\hline
\end{tabular}

**. Correlation is significant at the 0.01 level (2-tailed).

*. Correlation is significant at the 0.05 level (2-tailed).

The table indicates that there was a strong positive correlation between utilisation of human resource strategy evaluation (and its dimensions) and performance of human resource strategy in universities $(r=0.608)$. Were human resource strategy evaluation and performance measured in discreet units, the correlation coefficient value of $r=0.608$ would imply that for every unit (100\%) change in the utilisation of human resource strategy evaluation, there would be a corresponding $0.608(60.8 \%)$ change in the performance of the human resource strategy. In this study, it suffices to assert that the positive correlation between the two variables suggests the higher the utilisation of the human resource strategy evaluation, the higher is the level of performance of an organisation, and vice versa. 
The analysis further shows that $p\{0.000\}<0.01$, which was less than the hypothesised $\alpha=0.05$. Consequently, this inquiry rejected the null hypothesis and concluded that there was a significant relationship between utilisation of human resource strategy evaluation and performance of the human resource strategy in universities in Kenya. The finding, then, establishes a nexus between human resource strategy evaluation and the performance of the human resource strategy. This is consistent with (Hieu \& Nwachukwu, 2019), (Kazmi, 2008), Digman (2003), Certo and Peter (1993), and Ghosh (2010). Performance is enhanced by forestalling risk (Hieu \& Nwachukwu, 2019; Certo \& Peter, 1993), establishing validity of the strategy in the first place (Rumelt 1979 in Ghosh, 2010), derivation of critical success factors and hence providing a road map (Digman, 2003), establishing congruence between levels of strategy (Kazmi, 2008), and fostering learning and development from evaluation data (GPE, 2017).

In addition to the overall relationship, the study further established the relationship between individual dimensions of utilisation of human resource strategy evaluation and performance of human resource of the human resource strategy in universities in Kenya. Table 3.3 indicates that there was a moderate positive correlation between the utilisation of Consistency in the human resource strategy and performance of human resource of the human resource strategy $(r=0.400)$. Were units of measurement discreet, the correlation coefficient value of $r=0.400$ is interpreted as follows: for every unit (100\%) change in the utilisation of the principle of the Consistency in the human resource strategy evaluation, there would be a $0.400(40.0 \%)$ change in the performance of human resource of the human resource function. The positive correlation between the two variables suggests the higher the utilisation of consistency of the human resource strategy evaluation, the higher is the level of performance of an organisation, and vice versa. Since the $p\{0.026\}<0.05$, the study, therefore, rejected the null hypothesis and concluded that there was a significant relationship between utilisation of the Consistency in human resource strategy evaluation and performance of human resource function in universities in Kenya. This suggests the human resource strategy evaluation was linked to overall institutional strategy, the mission, and vision of the institutions.

Table 3.3 also indicates that there was a moderate positive correlation between the utilisation of the Consonance (Suitability) principle in human resource strategy and performance of human resource strategy $(r=0.471)$. Were Consonance and performance measured in discreet units, the correlation coefficient value of $r=0.471$ would mean that for every unit $(100 \%)$ change in the utilisation of Consonance in human resource strategy evaluation, there would be $0.471(47.1 \%)$ change in the performance of human resource function. The positive correlation between the two variables suggests the higher the utilisation of consonance of the human resource strategy evaluation, the higher is the level of performance of an organisation, and vice versa. As the $p\{0.007\}<0.01$, the study rejected the null hypothesis and concluded that there was a significant relationship between utilisation of the Consonance principle in human resource strategy evaluation and performance of the human resource strategy in universities in Kenya. The human resource strategy passed the goodness of fit test, i.e, it is well-matched to its environment (Thompson, Gamble \& Strickland, 2004), and thus avoids strategic drift, hypocrisy and consequently earning legitimacy. The finding, however, is inconsistent with Junior, Pascuci, and Meyer (2018) who found universities marred by strategic tensions between the macro and micro levels.

Table 3.3 further indicates that there was a moderate positive correlation between the utilisation of Advantage principle in human resource strategy evaluation and the 
performance of the human resource function $(r=0.530)$. Again, were the units of measurement of Advantage and performance are to be discreet, the correlation coefficient value of $r=0.530$ would imply that for every unit $(100 \%)$ change in the utilisation of Advantage in human resource strategy evaluation, there would be a 0.530 (53.0\%) change in the performance of the Human resource function. The positive correlation between the two variables suggests the higher the utilisation of the Advantage principle in human resource strategy evaluation, the higher is the level of performance of the of human resource unit and vice versa.

The analysis also yielded a corresponding $p\{0.002\}<0.01$. Consequently, the researcher rejected the null hypothesis concluding that there was a significant relationship between utilisation of Advantage in human resource strategy evaluation and performance of the human resource unit in universities in Kenya. It has to do with superiority in resources, skills, and position (Rumelt 1979 as cited by David, 2013). To bring Advantage, people must feel something, have something, and do something (Wright, 2008). In military strategy, position meant ground (Adair, 2010; Sun Tzu, n.d.), universities live on reputations (position) usually built by its human resources and can be similarly threatened as in the case of unethical behaviour.

Table 3.3 also indicates that there was a moderate positive correlation between the utilisation of the Feasibility principle in human resource strategy and performance of the human resource function $(r=0.539)$. Again, were the units of measurement discreet, the correlation coefficient value of $r=0.539$ would have meant that for every unit $(100 \%)$ change in the utilisation of Feasibility in human resource strategy evaluation, there was a $0.539(53.9 \%)$ change in the performance of human resource function. The positive correlation between the two variables suggests the higher the utilisation of the Feasibility principle in human resource strategy evaluation, the higher is the level of performance, and vice versa. This is logical and expected as Feasibility connotes workability or practicality of the human resource; the more workable the strategy, the more it is likely to contribute to human resource success.

Additionally, the table shows a corresponding $p\{0.002\}<0.01$. Thus, the study rejected the null hypothesis and concluded that there was a significant relationship between utilisation of Feasibility in human resource strategy evaluation and performance of the human resource strategy in universities in Kenya. Feasibility is vital in the face of strategic decisions that are large, involving significant resources, are long-term, and have irreversible consequences (Johnson \& Scholes, 1997). Human resource planning is a form of feasibility analysis. Thus, human resource demand and supply forecasts enable organisations to anticipate future human resource needs and plan recruitment, retrenchments, compensations, and deployments. The whole human resource project is evaluation of the current and future human resource requirements and how to meet them. This in turn has implications on the overall strategy. The finding is consistent with Muma et al. (2019) who found human resource planning positively associated with retention of employees in Kenyan universities. But the finding is inconsistent with Mkandatsama and Nyanhete (2017) who found the unstable economy affecting human resource planning in state universities.

\section{Regression Analysis}

To reinforce the findings of the correlation analysis above, the study employed the regression analysis technique, which estimates the amount of change in the dependent variable that can be explained by the independent variable. In regression analysis, an independent variable is used to explain and/or predict the values or changes in a dependent variable (Canavos \& 
Miller, 2001) thereby pointing the way to the possibility of some causality. The study based the regression analysis on a stochastic regression, single linear model of the general form, $y=a+\beta_{1} x_{1}+e$, tested at $\alpha=0.01$ significance level (99\% confidence level). Table 3.4 presents a summary of the regression results.

Table 3.4: Regression Model Summary

\begin{tabular}{rccc}
\hline $\mathrm{R}$ & R Square & Adjusted R Square & Std. Error of the Estimate \\
\hline $.608^{\mathrm{a}}$ & .369 & .347 & 6.760 \\
\hline
\end{tabular}

a. Predictors: (Constant), Utilisation of Human resource Strategy Evaluation

The table 3.4 presents the values of $\mathrm{R}, \mathrm{R}^{2}$, Adjusted $\mathrm{R}^{2}$, and the standard error of the estimate. The value of $R^{2}$, the coefficient of determination, defines the percentage of the variations in the dependent variable (performance of the human resource strategy) explained by a given model (utilisation of human resource strategy evaluation). In this study, the contribution of the utilisation of human resource strategy evaluation to the performance of the human resource strategy was $R^{2}=0.347$. Therefore, the regression model indicates that the independent variable (utilisation of human resource strategy evaluation) explained or accounted for $34.7 \%$ of changes in the level of performance of the human resource strategy. This then means, that other variables (factors) not included in this model contributed to the remaining $65.3 \%$ of changes in the level of performance of human resource strategy. With $R$ and $R^{2}$, the study needed to determine the significance or otherwise of this contribution.

The researcher utilised the Analysis of Variance (ANOVA), F-test, to check the overall significance of the regression model. The rule is to compare the calculated $p$ value and the significance value, $\alpha$. Where $p$ is less than the significance value, $\alpha$, then the regression model is considered significant, and vice versa. Table 3.5 shows a summary of the significance of the influence of the independent variable on the dependent variable based on the F-test.

Table 3.5: Analysis of Variance F-Test Results

\begin{tabular}{|c|c|c|c|c|c|c|}
\hline \multicolumn{2}{|c|}{ Model } & $\mathrm{SS}$ & Df & MS & $\mathrm{F}$ & Sig. \\
\hline \multirow[t]{3}{*}{1} & Regression & 775.682 & 1 & 775.682 & 16.975 & $.000^{\circ}$ \\
\hline & Residual & 1325.157 & 29 & 45.695 & & \\
\hline & Total & 2100.839 & 30 & & & \\
\hline
\end{tabular}

a. Dependent Variable: Performance of Human resource Strategy

b. Predictors: (Constant), Utilisation of Human resource Strategy Evaluation

In the table, it is evident that since $F(1,30)=16.975$ and $p(000<0.01)$, the researcher concluded that the regression model was statistically significant, and therefore adequate, in predicting the influence of utilisation of human resource strategy evaluation on performance of human resource strategy in universities in Kenya.

The final step in the regression analysis was the derivation of the regression model. The step requires the presence of a constant term and the regression coefficients of the independent and dependent variables. Table 3.6 presents summaries of these quantities. 
Table 3.6: Regression Coefficients

\begin{tabular}{|c|c|c|c|c|c|c|}
\hline \multirow{2}{*}{\multicolumn{2}{|c|}{ Model }} & \multicolumn{2}{|c|}{$\begin{array}{l}\text { Unstandardised } \\
\text { Coefficients }\end{array}$} & \multirow{2}{*}{$\begin{array}{c}\text { Standardised } \\
\text { Coefficients } \\
\text { Beta }\end{array}$} & \multirow[b]{2}{*}{$\mathrm{t}$} & \multirow[t]{2}{*}{ Sig. } \\
\hline & & B & $\begin{array}{r}\text { Std. } \\
\text { Error }\end{array}$ & & & \\
\hline \multirow[t]{2}{*}{1} & (Constant) & 6.820 & 10.263 & & .665 & .512 \\
\hline & HES index score & 679 & .165 & .608 & 4.120 & .000 \\
\hline
\end{tabular}

a. Dependent Variable: Performance

Table 3.6 gives the regression coefficient $(\beta)$ of the independent variable. The $\beta$ measures the amount of change in the dependent variable associated with one unit change in each independent variable. From the table, the independent variable had a positive regression coefficient, $\beta$ value, suggesting that it had a positive influence on performance. From the $t-$ values, the independent variable had a significant and positive influence on the dependent variable. From the positive sign of the standardised regression coefficient, $\beta$, the direction of the relationship was inferred.

Substituting these standardised regression coefficients $(\beta)$ in the regression model, $=a+\beta_{1} x_{1}+e$, provides the following equation: $y=6.820+0.608 x_{1}+e$, where, $\mathrm{y}=$ performance of human resource strategy evaluation (HSE -dependent variable), $\mathrm{a}=$ constant,

$\beta_{1}=$ regression coefficient of the HSE, $x_{1}=\mathrm{HSE}$ (independent variable), $e=$ error term. The decision this study reached was that the model was significant. The sample data contradicted the null hypothesis, which the researcher accordingly rejected.

But by what mechanism does this kind of evaluation contribute to the performance of the human resources? First it points to the strategy's validity, through a rigorous situational analysis via environmental scanning and analysis (Certo \& Peter, 1993). This in turn guides strategic choice. Ideally, little, if any, should go wrong from the very beginning. Secondly, it points out the key areas of strategic intervention, the critical success factors for performance (Certo \& Peter, 1993) by showing a cause-effect relation among factors of performance. Thirdly, it brings out information about the need for either corrective action (where there are deficiencies) or improvement (where things are going as planned). Finally, HSE measures the actual contribution of the strategy to performance thereby justifying the value of the investment. The underlying mechanism is data, information processing and knowledge accumulation within the strategising entity or evaluand. It is the data, information, and knowledge that enables strategists to make sound strategic choices and make sound decisions for interventions and worth strategies.

The finding is consistent with the World Bank (2019), Hieu and Nwachukwu (2019), Anya, Umoh, Worlu (2017), Walsh, Sturman, Longsheet (2010), Nayeri, Mashhadi, and Mohajeri (2008). In a similar study, Hieu and Nwachukwu (2019) concluded that strategy evaluation process was a good predictor of variations in strategic performance of the mobile telecommunication firms in Nigeria, with $R^{2}=0.3102$ and $\beta_{1}=0.319$. In their study, Anya, Umoh, Worlu (2017) found that strategic action had a positive influence on customer satisfaction and productivity. In their study, Nayeri, Mashhadi, and Mohajeri (2008) found use of the balanced scorecard (BSC) relevant in evaluating the strategic position of higher education institutions. And the World Bank (2019) reported on the performance contracting in universities as a mechanism to attract additional funding. In contrast, Walsh, Sturman, Longsheet (2010) argued that entities that manage their Human resources more strategically, including Human resources, stood to reap greater returns. 
But drawing conclusions about utilisation of the human strategy evaluation could be premature. The assumption that universities carry out systematic evaluations merely because they formulate strategic plans is problematic. Strategic planning itself is relatively new in Kenyan universities. Research in this area is therefore, fledgling, and evidence of success or failure is inconclusive. Furthermore, there is consensus in literature that strategy evaluation generally, and human strategy evaluation particularly, is an area that is under-researched. Bernadin (2007) and Aspromourgos (2012) consider the underdevelopment of metrics the main obstacle, just like human resources management practice itself appears still rooted in the orientation of personnel management (Aswathappa, 2008; UNICEF, 2007).

\section{Conclusion and Recommendation}

The study reported in this paper sought to domesticate the business strategy evaluation dimensions to the evaluation of the human resources strategy. It also sought to determine the relationship between the utilisation of human resources strategy evaluation and performance of human resource strategy in universities in Kenya. The researcher domesticated the principles of business strategy evaluation (consistency, consonance, feasibility, and advantage) to the evaluation of the human resource strategy. Surprisingly, this aspect of strategy was not attempted prior to this study. The study established a positive and significant relationship between the utilisation of these principles and the performance of the human resource strategy as measured by efficiency, effectiveness, and impact. The researcher rejected the hypothesis of non-significance of the relationship. The findings have implication for the development of the Human resources management discipline in theory and practice. This is the case particularly in the design of analytics and performance indicators that still pose a challenge in Human resources management. The study recommends extension of this thinking to industry.

\section{Research Limitation and Directions for Future Studies}

This study presented several limitations. One entailed single respondent. The study targeted the administration registrar alone as the respondent thus, limited the perspective of the study. The study was subjective in its measures of human resource strategy evaluation as well as its performance; this blurred the real effect of the variables on each other. The strategy is long-term in nature such that its effects are not felt in the short-term. A cross-sectional inquiry is, therefore, limited in looking into long-term consequences of strategy. The study recommends use of more objective measures of strategy and performance. Longitudinal studies are recommended to cover the full range of strategy as laid out in five-year strategic plans. Future studies could also target top management teams, heads of department (line managers), and employees in a 360-degree effort.

\section{References}

Adair, J. (2010) Effective Leadership: The Complete Guide to Strategic Management. London: Pan Books.

Adom, D., Hussein, E. K. \& Agyem, J. A. (2018) Theoretical and Conceptual Framework: Mandatory Ingredients of A Quality Research, in International Journal of Scientific Research, 7(1), pp. $2277-8179$.

Ali, M., Ahmad, Z. \& Iqbal, J. (2012) Human resource planning: A key to internal and external Fit, in African Journal of Business Management, 6(27), pp. 7938-7941, 11 July, 2012. 
Allui, A. \& Sahn, J. (2016) Strategic Human Resource Management in Higher Education Institutions: Empirical Evidence from Saudi, in the Procedia - Social and Behavioral Sciences, 235(6), pp. $361-371$.

Amaeshi (2014) Human Resource Management Practices and Employee retention in Nigeria's Manufacturing industries, in International Journal of Scientific \& Engineering Research, 5(2).

Amaeshi (2013) The Impact of Strategic Integration of Human Resource Management Practices on Organizational Performance: Some Evidence from Nigeria, in International Journal of Scientific \& Engineering Research, 4(11).

Anya, C. J., Umoh, G. I., \& Worlu, G. (2017). Human resource planning and organization performance in Oil and gas firms in Port Harcourt, Nigeria. International journal of advanced academic research social and management science. 3(9).

Ashraf, C. \& Kadir, S. A. (2012) A Review on the Models of Organisational Effectiveness: A Look at Cameron's Model in Higher Education, in International Education Studies, 5(2).

Asiamah, N., Mensah, H. K., \& Oteng-Abayie, E. (2017) General, Target, and Accessible Population: Demystifying the Concepts for Effective Sampling, in The Qualitative Report, 22(6), 1607-1621.

Aspromourgos, T. (2012) The managerialist university: an economic interpretation, in the Australian Universities' Review, 54(2)

Aswathappa, K. (2008) Human Resource Management: Text and Cases, $5^{\text {th }}$ ed. New Delhi: Tata MCGraw-Hill Publishing Company Limited.

Athapaththu, H.K.S. H. (2016) An Overview of Strategic Management: An Analysis of the Concepts and the Importance of Strategic Management, in International Journal of Scientific and Research Publications, 6(2).

Ayanda, O. J. \& Sani, A. D. (2011) An Evaluation of Strategic Human resource Management (SHRM) Practices in Nigerian Universities: The Impact of Ownership Type and Age, in European Journal of Economics, Finance and Administrative Sciences. 32

Ayre, C. \& Scally, A. J. (2013) Critical Values for Lawshe's Content Validity Ratio: Revisiting

the Original Methods of Calculation Measurement and Evaluation, in Counseling and Development, 47(1) 79-86

Barnat, R. Strategic Management: Formulation and Implementation. Retrieved from https://www.24xls.com/. Accessed on February 23, 2021.

Barney, J. B., Corte, V. D., Sciarelli, M. \&Arikan, A. (2012) The role of resource- based theory in strategic management studies: managerial implications and hints for research. Ed. Dagnino, G. B., Handbook of Research on Competitive Strategy. Cheltenham, UK Edward Elgar.

Bayo-Moriones, A. \& de Cerio, J. M. (2002) Human Resource Management, Strategy and Operational Performance in the Spanish Manufacturing Industry, in Management 2002/3 (Vol. 5), p. 175-199. DOI 10.3917/mana.053.0175

Bernadin, H. J. (2007) Human Resource Management: An Experiential Approach. New Delhi: Tata McGraw-Hill Publishing Company Limited.

Bhusan, B. \& Sar, A. K. (2020) Contribution of strategic human resource management towards the growth of the modern era organisations: A research study on the Indian retail industry, in Eurasian Chemical Communications. 
Beurren, I. M. \& Teixeira, S. A. (2014) Evaluation of management control systems in a highereducation institution with performance management and control, JISTEM J.Inf.Syst.Technol. Manag. 11(1).

Boon, C., Eckardt, R., Lepak, D. P. \& Boselie, P. (2017) Integrating strategic human capital and strategic human resource management, in The International Journal of Human resource Management, 29:1, 34-67.

Bodor, M. (2014) 21ST Century Challenges of Human Resource Management in View of Hungarian Higher Educational Institutions' Operation. An Unpublished PhD Thesis, Kaposvár University, Hungary.

Boudreau, J.W. \&. Lawler, E.E. (2016) How to Measure HR Effectiveness. Retrieved from https://quarterly.talenteconomy.io/issue/fall-2017/how-to-measure-hreffectiveness/. Accessed: December 20, 2018.

Bratton, J. \& Gold, J. (2017) Human Resource Management: Theory and Practice, 6 th $^{\text {th }}$ ed.London: Red Globe Press.

Calabretta, G., Gemser, G. \& Wijnberg, N. M. (2017) The Interplay between Intuition and Rationality in Strategic Decision Making: A Paradox Perspective, in Organization Studies, 38(3-4) 365-401.

Canadian Evaluation Society (CES) What is Evaluation? CES. Retrieved from https://evaluationcanada.ca/. Accessed on February 16, 2021.

Canavos, G. C. \& Miller, D. M. (1993) An Introduction to Modern Business Statistics. Belmont, California: Duxbury Press.

Certo, S. C. \& Peter, J. P. (1993) Strategic Management: A Focus on Process, $2^{\text {nd }}$ ed. Burr Ridge, Illinois: Irwin.

Chakraborty, D. \& Biswas, W. (2019) Evaluating the impact of human resource planning programs in addressing the strategic goal of the firm: An organizational perspective, in Journal of Advances in Management Research Vol. 16 No. 5, 2019 pp. 659-68.

Cobert, F. (2017) The Importance of the Human resource Strategy. Bizfluent. Retrieved from bizfluent.com. Accessed on January 27, 2021.

Colbert, F. (September 26, 2017) The Importance of the Human resource Strategy. Bizfluent. Retrieved from. https://bizfluent.com/facts-5744528-salary-grades-salary-rangesimportant-.html. Accessed on February 15, 2021.

Commission for University Education (2017) University Statistics. Nairobi: Commission for University Education.

Coron, C. (2021) Quantifying human resource management: a literature review. Personnel Review. https://www.emerald.com/insight/0048-3486.htm. Accessed on September 12, 2021.

David, F. R. (2013) Strategic Management Concepts and Cases. Upper Saddle River, New Jersey.

Digman, L. A. (2003) Strategic Management: Competing in the Global Information Age, $7^{\text {th }}$ ed. Mason, Ohio: Thomson/Custom Publishing.

Egler, D. (n.d) Theory of Performance. Faculty Development Studies, University of Idaho. Retrieved from https://www.webpages.uidaho.edu/ele/scholars/Results/Workshops/Facilitators_Ins titute/Theory\%20of\%20Performance.pdf. Accessed on April 02, 2019.

Elena-Iuliana, I. \& Maria, C. (2016) Organisational Performance - A Concept that SelfSeeks to Find Itself, in Annals of the, Constantin Brâncuşi” University of Târgu Jiu, Economy Series, Issue 4/2016. 
Eneh, S. I. \& Awara, N. F. (2016) Strategic Human resource Management Practices and Organisational Growth: A Theoretical Perspective, in Global Journal of Social Sciences, 15 , pp. 27-37.

Fan, B. \& Wang, H. (2015) Evaluation of Traditional and Strategic Human resource Management at the International conference on Engineering Management, Engineering Education and Information Technology (EMEEIT 2015)

Forsell, M. (2012) 7th International Scientific Conference "Business and Management 2012" May 10-11, 2012, Vilnius, LITHUANIA.

Frankfort-Nachmias, C. \& Leon-Guerrero, A. (2011) Social Statistics for a Diverse Society, 6 "ed. Los Angeles: Sage Publications.

Ghosh, P. K. (2010) Strategic Planning and Strategic Management. New Delhi: Sultan Chand \& Sons.

Gonzalez, T., de la Rubia, M. A., Hincz, K. P., Comas-Lopez, M. \& Subirats, L. (2020) Influence of COVID-19 confinement in students performance in higher education. Retrieved from file://C:/Users/Isaiah\%20kibaro/Downloads/InfluenceofCOVID19confinementinstudentsperformanceinhighereducation\%20(1).pdf. Accessed on July 01, 2021.

Global Partnership for Education, GPE (2017) Monitoring and Evaluation Strategy. Retrieved from https://www.globalpartnership.org/content/gpe-monitoring-andevaluation-strategy-july-2017. Accessed on July 31, 2021.

Gupta, S.P. (1969) Statistical Methods, 31" ed. New Delhi: Sultan Chand \& Sons.

Hannon, J. M., Huang, I.\& Jaw, B. (1994) International Human resource Strategy and Control: The Case of Multinationals and Their Subsidiaries" (1994). Purdue CIBER Working Papers. Paper 84. http://docs.lib.purdue.edu/ciberwp/84. Accessed on February 04, 2021.

Hieu, V. M. \& Nwachukwu, C. E. (2019) Strategy Evaluation Process and Strategic Performance nexus, Researchgate. Retrieved from https://www.researchgate.net/publication/335960352_Strategy_evaluation_process _and_strategic_performance_nexus. Accessed on May 23, 2020.

Johnson. G. \& Scholes, K. (2008) Exploring Corporate Strategy, 4t ed. New York: Prentice Hall.

Jyoti, S. \& Mohsin, F. (2020) Current Practices and Challenges of Performance Management System In Higher Education Institutions: A Review, in Journal of Critical Reviews ISSN-2394-5125 Vol 7, Issu.e 7, 2020

Kafel, T. \& Ziebicki, B. (2021) Dynamics of the evolution of the strategic management concept: From the planning school to the neostrategic approach, in Journal of Entrepreneurship, Management and Innovation, ISSN 2299-7326.

Kazmi, A. (2008) Strategic Management and Business Policy, $3^{\text {td }}$ ed. New Delhi: Tata McGraw-Hill Education Private Limited.

Kiprop, C.J., Bomett, E. J. \& Michael, J. J. (2015) Strategic Planning in Public Secondary Schools in Kenya: Challenges and Mitigations, in International Journal of Advanced Research in Education \& Technology, 2(4).

Khan, A. A., Taher, M. A. and Islam, M., A (2021) Human Resource Management and Industrial Relations. 6th Edition, Abir Publication, Dhaka, Bangladesh.

Kothari, C. R. (1990) Research Methodology: Methods and Techniques. $2^{\text {nd }}$ Ed. Wishwa Prakashan. pp 104-107. 
Lapin, L. L. (1990) Statistics for modern business decisions, $5^{\text {th }}$ ed. Orlando: Harcourt Brace Jovanovich.

Lengnick-Hall, M. L., Lengnick-Hall, C. A., Andrade, L. S. \& Drake, B. (2009) Strategic human resource management: The evolution of the field, in the Human resource Management Review, 19(9) 64-85.

Loukkola, T., Peterbauer, H. \& May, A. G. (2020) Exploring higher education indicators. Brussels \& Geneva: European University Association.

Maunder, N., Visser, M., Hodson, B . \& Allan, S . (2014) Strategic Evaluation WFP's Use of Pooled Funds for Humanitarian Preparedness Response (2009-2013): A Strategic Evaluation. World Food Programme. Retrieved from www.wfp.org/evaluation. Accessed on May 24, 2020.

Mello, J. A. (2011) Strategic Human resources, $3^{\text {ra }}$ ed. Australia: South-Western/Cengage Learning

Mezentseva, L. V., Kurkov, K. N., Arsakhanova, Z. A., Martynenko, M. V., Takmakova,E. V. \& Guseva, T. G. (2018) Human resource management strategy: implementation features, prerequisites, and effective results, in Revista ESPACIOS. 39(31).

Mkandatsama, P. \& Nyanhete, T. (2017) Human Resource Planning in an Unstable Economy: Challenges Faced, A Case of State Universities in Zimbabwe, in International Journal of Asian Social Science, 2017, 7(3): 206-217, ISSN(e): 22244441/ISSN(p): 2226-5139.

Montanaro, M. K. (2013) The Influence of Financial Performance on Higher Education Academic Quality, an unpublished PhD Thesis.

Muraga, D. K. (2015) Strategic Human resource Management Practices and Performance of Parastatals in Kenya. An Unpublished PhD Thesis.

Muma, M. M., Onyiego, C., Nzulwa, J., Ombui, K., Odhiambo, R., \& Lumiti, P. A. (2019) Influence of Employer Branding Strategies on Retention of Employees in Universities in Kenya, in International Journal of Social Science and Humanities Research, 7(2), pp, 68-95.

Nayeri, M. D., Mashhadi, M. M. \& Mohajeri, K. (2008) Universities Strategic Evaluation Using Balanced Scorecard, in the World Academy of Science, Engineering and Technology International Journal of Educational and Pedagogical Sciences, 2(1).

Neuman, W.L. (2011) Social Research Methods: Qualitative and Quantitative Approaches, $6^{\text {th }}$ ed. Boston: Pearson.

Omalaja, M.A. \& Eruola, O. A. (2011) Strategic management Theory: Concepts, Analysis and Critiques in Relation to Corporate Competitive Advantage from the Resourcebased Philosophy, EA44(12)

Orajaka, U. P. (2021) Organisational Performance and its Effects to Employee Recognition and Job Satisfaction in Some Selected Public Universities in the South East, Nigeria, in Asian Journal of Economics, Business and Accounting, 21(3): 97-106.

Oxford Reference (2020) Internal Fit. Oxford: Oxford Press. Retrieved from https://www .oxfordreference.com/view/10.1093/oi/authority.20110803100007206. Accessed on July 31, 2021.

Palladan, A. A. \& Adamu, M.A. (2018) An Overview of Strategic Management Practice, in Austin J Bus Adm Manage.2(3): 1033-1041.

Pearce, J.A. \& Robinson, R.B. (2011) Strategic Management: Planning for Domestic and Global Competition. New York: McGraw-Hill.

Pintea, M. O. \& Achim, M. V. (2013) Performance - An Evolving concept. Available at https://core.ac.uk/download/pdf/6239858.pdf. Accessed on April 02, 2019. 
Priyan, S. \& Oinam, J. (2015) Evaluation of a National Health Programme. Retrieved from slideshare.net. Accessed on February 16, 2021.

Rahma, H. \& Al Mamun, A. (2013) Human Resource Management: Focus on Distinctive Human Capital and Strategy of Building-Retaining Competitive Advantage in Global Journal of Management and Business Research Administration and Management Volume 13 Issue 11 Version 1.0 Year 2013.

Republic of Kenya (2017) Human Resource Framework for the Public Service. Nairobi: Ministry of Public Service, Youth and Gender Affairs.

Republic of Kenya (2014) Health Sector Human resources Strategy 2014 - 2018. Nairobi: Ministry of Health.

Rumelt, R.P. (1979) Evaluation of Strategies: Theory and Models. In: Schendel, D.E. and Hofer, C.W., Eds., Strategic Management: A New View of Business Policy and Planning, Little, Brown, Boston.

Salkind, N. J. (2000) Exploring Research, $4^{\text {th }}$ ed. Upper Saddle River, New Jersey: Prentice Hall.

Sepahvand, R. \& Khodashahri, R. B. (2021) Strategic Human Resource Management Practices and Employee Retention: A Study of the Moderating Role of Job Engagement, in Iranian Journal of Management Studies, 14(2): 437-468.

Serfontein, C. (2016) The rational approach to strategy. Accounting Weekly. Retrieved from. Accountingweekly.com. Accessed on February 15, 2021.

Sharma, S. \& Al Sinaw, S. (2021) Organisational Performance Influenced by Academic Service Quality: An Investigation in Public Universities in Malaysia, in Hindawi Education Research International Volume 2021.

Shaughnessy, J. J., Zechmeister, E. B. \& Zechmeister, J. (2006) Research Methods in Psychology, $7^{\text {t }}$ ed. Boston: McGraw Hill Higher Education.

Shroufa, H., Al-Qudaha, S., Al Khawaldehb, K., Obeidatc, A. M. \& Al Rawashdehd, A. (2020) A study on relationship between human resources and strategic performance: The mediating role of productivity, in Management Science Letters 10 (2020) 3189_ 3196.

Simonsi, A. (InLoox Blog, Monday 22 February 2021) Why People Are the Most Important Resource in the Company. Available at https://www.inloox.com/company/blog/articles/why-people-are-the-mostimportant-resource-in-the-company/. Accessed on September 12, 2021.

Snell, S. A. (1992). Control theory in strategic human resource management: The mediating effect of administrative information. Academy of Management Journal, 35(2), 292327. https://doi.org/10.2307/256375.

Sun Tzu (n.d) The Art of War, translated Cleary, T. (2005). Boston ^ ${ }^{\wedge}$ London: Shambhala.

Taber, K. S. (2018) The Use of Cronbach's Alpha When Developing and Reporting Research Instruments, in Science Education, in Res Sci Educ, (8).

Tahir, S. (2020) Organisational Performance: What it is and how to measure it. CQ Net. Retrieved from https://www.ckju.net/en/organisational-performance-what-it-ishow-to-measure-and-improve-it. Accessed on July 04, 2021.

Thomas, M. (1996) What is Human Resource Strategy? Health Manpower Management Volume $22-$ Number 2 - 1996 - pp. 4-11. Retrieved fromhttps://pdfs.semanticscholar.org. Accessed: April 01, 2019.

Torrington, D., Hall, L. \& Taylor, S. (2008) Human Resource Management, $7^{\text {th }}$ ed. Harlow, England: Prentice Hall/Financial Times. 
UNICEF (2005) Strategic Review of Human Resource Management in UNICEF. New York. UNICEF.

Urmila, K. (n.d) Functional Strategy. Business Management Ideas. Retrieved from businessmanagementideas.com. Accessed on February 15, 2021.

vanVulpen, E. (2020) How to Create a Human resource Strategy. AIHRM Digital. Retrieved from https://www.digitalhuman resourcetech.com/human-resourcestrategy/.Accessed on February 04, 2020.

Vidal, J. and Ferreira, C. (2020) Universities Under Pressure: the Impact of International University Rankings, in Journal of New Approaches, In Educational Research 2020, 9(2), 181-193,

Walsh, K., Sturman, M. C. \& Longsheet, J. (2010) Key Issues in Strategic Human Resources, in the Scholarly Commons, Cornell University School of Hotel Administration.

Wheelen, T. L. \& Hunger, J. D. (2011) Strategic Management and Business Policy, $11^{\text {th }}$ ed. Upper Saddle River, NJ: Pearson/Prentice Hall.

World Bank (2019) Improving Higher Education in Kenya: A Policy Report. Washington: World Bank.

Wright, T. (Oct 30, 2019) The Strategic Management Process. Cascade. Retrieved from https://www.cascade.app/blog/strategic-management-process. Accessed on February 23, 2021.

Wright, T. (Sept. 26, 2019) Aligning functional strategy with corporate strategy. Cascade. Retrieved from cascade.app. Accessed on February 5, 2021.

Wright, P. M. (2008) Human Resource Strategy: Adapting to the Age of Globalization. Duke Street, Alexandria: SHRM Foundation.

Yadav, R.S. (2011) Strategic Evaluation and Control. Retrieved from https://www .slideshare.net/RADHEY06/strategic-evaluation-and-control.

Accessed: December 20, 2018.

Zamanzadeh, V., Ghahramanian, A., Rassouli, M., Abbaszadeh, A., AlaviMajd, H., \& Nikanfar, A. (2015) Design and Implementation Content Validity Study: Development of an instrument for measuring Patient-Centered Communication, in Journal of Caring Sciences, 2015, 4(2), 165-178. 